\title{
Progress in Clinical Neurosciences: The Neuropathogenesis of HIV Infection: Host-Virus Interaction and the Impact of Therapy
}

\author{
C. Power, M.J. Gill, R.T. Johnson
}

\begin{abstract}
Despite the availability of highly active antiretroviral therapy (HAART), primary HIV-related neurological diseases remain major problems in HIV clinics. The present review examines the pathogenesis of HIV-related dementia and the less severe minor cognitive and motor deficit, together with distal sensory and drug-induced toxic polyneuropathies. Abnormal host immune responses within the nervous system and the role of viral expression and diversity are emphasized in relation to neurovirulence. Induction of innate immune responses within the central and peripheral nervous systems, largely mediated by cells of macrophage lineage, appear to be common to the development of primary HIV-related neurological disease. Activation of these cell types results in the release of a cascade of inflammatory molecules including cytokines, chemokines, matrix metalloproteinases, and arachidonic acid metabolites that influence neuronal survival. Individual viral proteins encoded by envelope and tat genes and discrete sequences within these genes influence the extent to which these pro-inflammatory molecules are induced. At the same time, systemic immune suppression may influence the occurrence and severity of HIV-related neurological diseases. Implementation of HAART and neuroprotective treatments improves neurological function although the evolution of drug-resistant viral strains limits the sustained benefits of HAART.
\end{abstract}

RÉSUMÉ: La neuropathognèse de l'infection par le VIH: interaction hôte-virus et impact du traitement. Malgré la disponibilité de la thérapie antirétrovirale hautement efficace (HAART), les maladies neurologiques reliées à l'infection par le VIH demeurent un problème majeur dans les cliniques de traitement de l'infection par le VIH. Cette revue examine la pathogenèse de la démence reliée au VIH et des déficits cognitifs et moteurs de moindre importance, ainsi que les polyneuropathies sensitives distales, induites par la toxicité des médicaments. Les réponses immunitaires anormales de l'hôte dans le système nerveux et le rôle de l'expression et de la diversité virale sont soulignés en relation avec la neurovirulence. L'induction des réponses immunitaires innées dans le système nerveux central et périphérique, en grande partie médiée par les cellules de la lignée macrophagique, semble être commune au développement des maladies neurologiques reliées au VIH. L'activation de ces types de cellules provoque la libération d'une cascade de molécules inflammatoires incluant des cytokines, des chemokines, des métalloprotéinases de la matrice et des métabolites de l'acide arachidonique qui influencent la survie neuronale. Des protéines virales individuelles codées par des gènes de l'enveloppe et des gènes tat, ainsi que des séquences discrètes dans ces gènes, influencent le niveau d'induction de ces molécules pro-inflammatoires. De plus, la suppression immunitaire systémique peut influencer l'apparition et la sévérité de maladies neurologiques reliées au VIH. Le traitement HAART et les traitements neuroprotecteurs améliorent la fonction neurologique, bien que l'évolution de souches virales résistantes à la médication limite les bénéfices à long terme du traitement HAART.

Can. J. Neurol. Sci. 2002; 29: 19-32

Over 55 million individuals, worldwide, have been infected by the human immunodeficiency virus, type 1 (HIV-1); ${ }^{1}$ greater than $90 \%$ of those infected will develop a neurological disease. ${ }^{2}$ The development of AIDS is defined by a decline in CD4 T cell levels below 200 cells/ $\mu 1$ in blood, with or without an AIDSdefining illness. This fall in CD4 cells is accompanied by increasing viremia and opportunistic infections (Figure 1). Since the publication of our earlier review, ${ }^{3}$ the understanding and treatment of HIV/AIDS-related neurological disorders has advanced, particularly with the advent of highly active antiretroviral therapy (HAART). This review highlights new developments in HIV neuropathogenesis.

\section{Neurological Aspects}

Early in the HIV epidemic, two general categories of neurological diseases were recognized as HIV infection progressed to AIDS; the first group includes opportunistic

From the Departments of Clinical Neurosciences (CP), Medicine (MJG), Microbiology and Infectious Diseases (CP, MJG), University of Calgary, Calgary AB, Canada and Department of Neurology (RTJ), Johns Hopkins University, Baltimore MD, USA. RECEIVED MAY 7, 2001. ACCEPTED IN FINAL FORM OCTOBER 5, 2001.

Reprint requests to: Christopher Power, Department of Clinical Neurosciences, 3330 Hospital Drive NW, Calgary, Alberta, Canada, T2N 4N1. E-mail: power@ucalgary.ca 


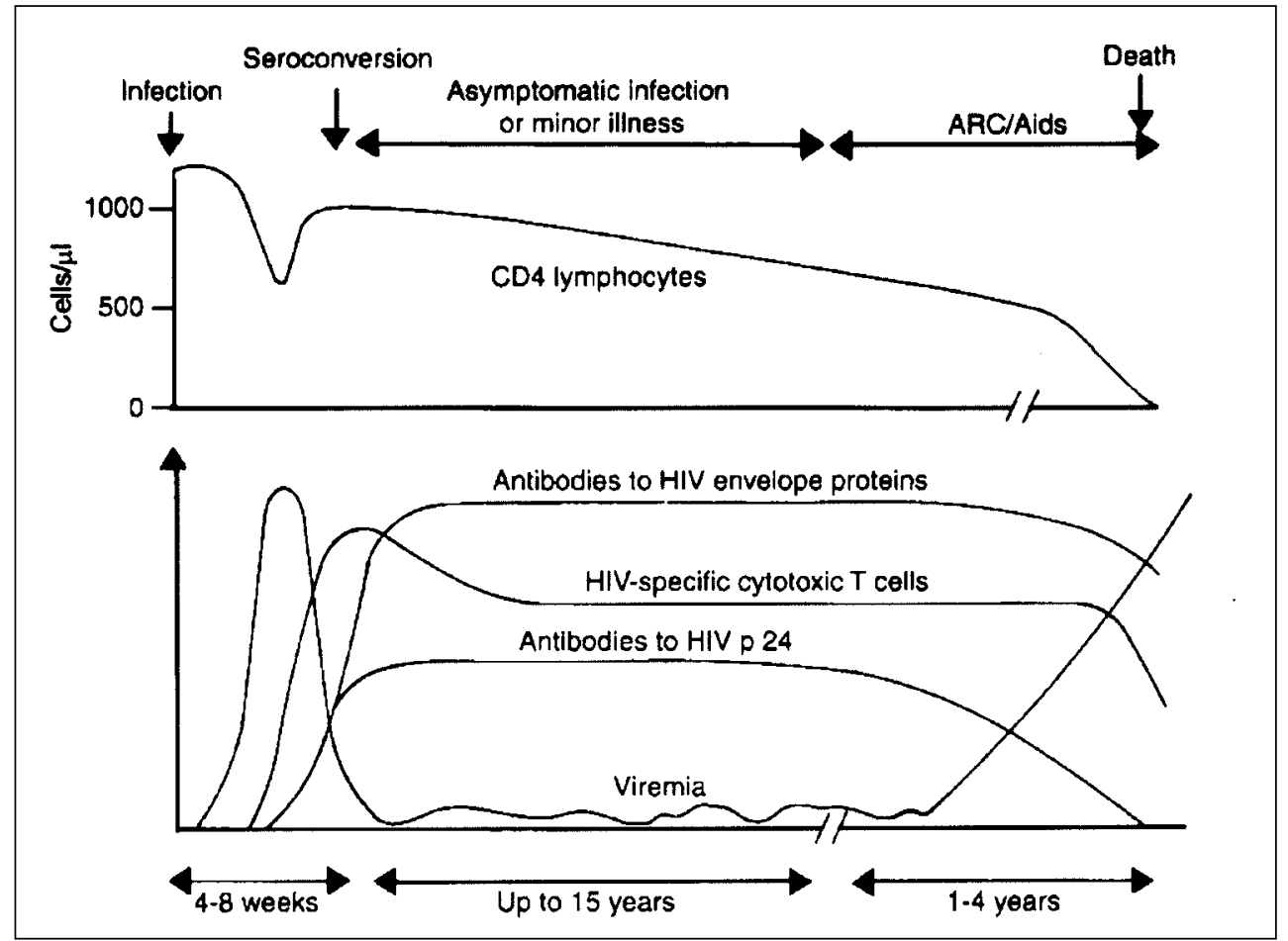

Figure 1: Disease course in HIV infection. Following primary infection there is a rapid transient rise in plasma viremia accompanied by a decline CD4+ lymphocyte count, which resolves over time. However, viral replication continues throughout infection and escalates with the development of AIDS with a concomitant drop in CD4+ cells below 200-cells/ul in blood. (After Johnson RT. Viral Infections of the Nervous System. Lippincott-Raven Publishers, 1998, with permission from Lippincott-Raven Publishers) $A R C=A I D S$ related complex

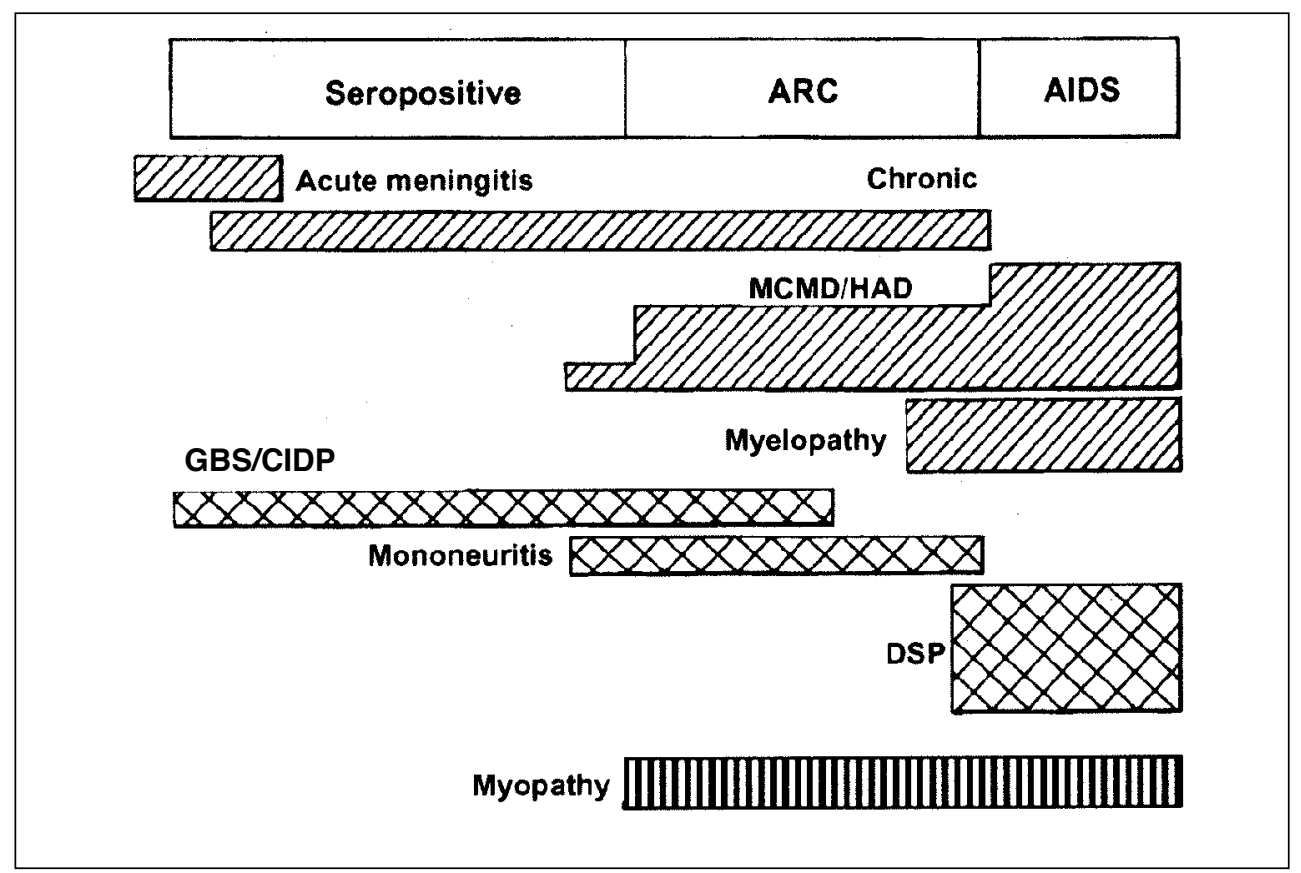

Figure 2: Neurological diseases occurring during the course of HIV infection. All levels of the neural axis may be affected by HIV infection but the individual syndromes usually emerge depending on the level of immune suppression. HAD, MCMD and DSP present during advanced infection.(After Johnson RT. Viral Infections of the Nervous System. Lippincott-Raven Publishers, 1998, with permission from Lippincott-Raven Publishers)

GBS/CIDP = Guillain-Barré syndrome/chronic inflammatory demyelinating polyneuropathy; DSP $=$ distal sensory polyneuropathy; $H A D=H I V$-related dementia $; M C D C=$ minor cognitive and motor deficit 


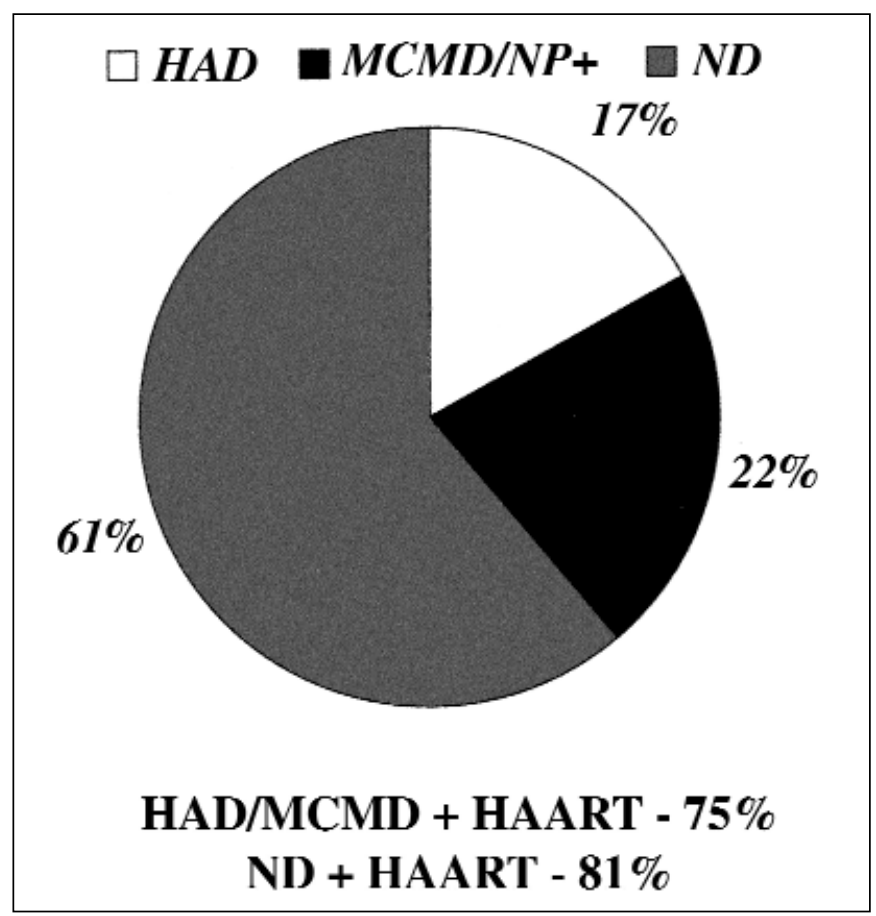

Figure 3: Prevalence of neurocognitive impairment in a subset of patients $(n=150)$ with HIV infection, followed at the Southern Alberta Clinic, Calgary $A B$. The level of immune suppression among patients with or without neurocognitive impairment did not differ significantly. Patients treated with HAART (HAD/MCMD-75\%; ND (nondemented)$81 \%)$ were receiving three or more antiretroviral drugs (NP+; abnormal results on neuropsychological testing).

infections of the central nervous system (CNS), while the second group are the primary HIV-induced syndromes. The latter syndromes include HIV-associated dementia (HAD), minor cognitive and motor deficit (MCMD), vacuolar myelopathy (VM), and several peripheral neuropathies ${ }^{4}$ (Figure 2). Other neurological syndromes have emerged, particularly with the advent of HAART including stroke-like events.

\section{Neurocognitive impairment}

Estimates of HAD prevalence rates in the pre-HAART era range from 5-20\% among patients with AIDS, ${ }^{5}$ while MCMD may affect as many as $30 \%$ of HIV/AIDS patients. ${ }^{6}$ The diagnostic criteria for both conditions have been defined in previous reports. ${ }^{7}$ Despite the wide availability of HAART, HIVrelated neurocognitive impairment is a common problem observed in HIV clinics (Figure 3). Risk factors for HAD include low CD4 levels, high viral loads in CSF or plasma, anemia and extremes of age. HIV-associated dementia is characterized by progressive motor, cognitive and behavioral abnormalities ${ }^{3}$ and displays remarkable diversity in its clinical phenotype. ${ }^{8-10}$ The course of the dementia is variable with an abrupt decline in function over weeks among some individuals, while others display a protracted course over several years. Prior to the availability of HAART in 1996, the mean survival with HAD was three to six months. Since 1996, the incidence of HAD has diminished, but the prevalence may be rising due to longer survival times. ${ }^{11,12}$ Minor cognitive and motor deficit exhibits many clinical aspects of HAD although the signs and symptoms are less severe. ${ }^{13}$ The relationship between HAD and MCMD remains uncertain but a subset of patients progress from MCMD to HAD. ${ }^{14}$ Radiological features accompanying HAD include cerebral and basal ganglia atrophy and white matter hyperintensities on MRI T2 weighted images. ${ }^{15,16}$ Recent magnetic resonance spectroscopy studies show diminished $\mathrm{N}$ acetyl aspartate levels in brain, implying neuronal injury or loss. ${ }^{17}$

The neuropathological hallmarks of HIV infection in the adult include multinucleated giant cells, diffuse white matter pallor, perivascular cuffs comprised of monocytes and lymphocytes, microglial nodules or the presence of HIV-1 antigens. ${ }^{18-20} \mathrm{HIV}$ encephalitis is defined by the presence of multinucleated giant cells and/or the presence of viral antigens. Among HIV-infected adults with dementia, approximately $20-80 \%$ of individuals will display multinucleated giant cells. ${ }^{18,21,22}$ Diffuse white matter pallor shows sparing of the $\mathrm{U}$ fibers and preserved myelin proteins; deposition of serum proteins in white matter suggests altered permeability of the blood brain barrier rather than demyelination. ${ }^{23,24}$ These findings are complemented by studies showing apoptotic cell death in cerebral endothelia in brains of HIV-infected patients. ${ }^{25}$

A limited correlation exists between HAD (a clinical entity) and HIV encephalitis (a pathological entity). Over half of adult AIDS patients with dementia do not exhibit diffuse myelin pallor or multinucleated giant cells at autopsy while microglial nodules may be present in $90 \%$ of autopsied AIDS patients including those without dementia. ${ }^{26,27}$ A correlation between HIV antigen abundance and HAD has been proposed. ${ }^{28}$ Other studies have shown that macrophage and microglia activation, particularly in the basal ganglia, is a stronger predictive marker for HIV dementia. ${ }^{26}$ Neuronal injury and death, in the frontal cortex and deep gray matter occurs in the brains of patients with AIDS. ${ }^{29-31}$ These neuronal abnormalities are likely responsible for the phenotypic expression of HAD.

\section{Myelopathy}

HIV-associated VM affects 5-10\% of AIDS-defined patients, usually manifesting as subacute progressive gait ataxia, leg weakness, spasticity, incontinence and may occur independently of neurocognitive impairment. ${ }^{32}$ The incidence of VM has also dropped with HAART to a point that it is infrequently seen in HIV clinics except in severely immunosuppressed patients. ${ }^{33}$ The diagnosis is one of exclusion of other conditions causing chronic myelopathy, which requires cerebrospinal fluid (CSF) analysis and imaging studies. Autopsy studies prior to HAART showed that $20-50 \%$ of AIDS patients exhibited axonal injury, macrophage infiltration and activation including multinucleated giant cells, and a vacuolar appearance that was primarily localized in the lateral and dorsal columns of thoracic spinal cord. The vacuolar appearance may reflect intramyelinic edema. Approximately $25 \%$ of patients with pathologically confirmed VM presented with antemortem symptoms or signs suggestive of a myelopathy. Although HAART appears to reduce the incidence of VM, limited reversal of the signs or symptoms is observed after therapy is implemented.

\section{Neuropathies}

Despite a decline in incidence of CNS manifestations associated with advanced HIV infection, the incidence and 


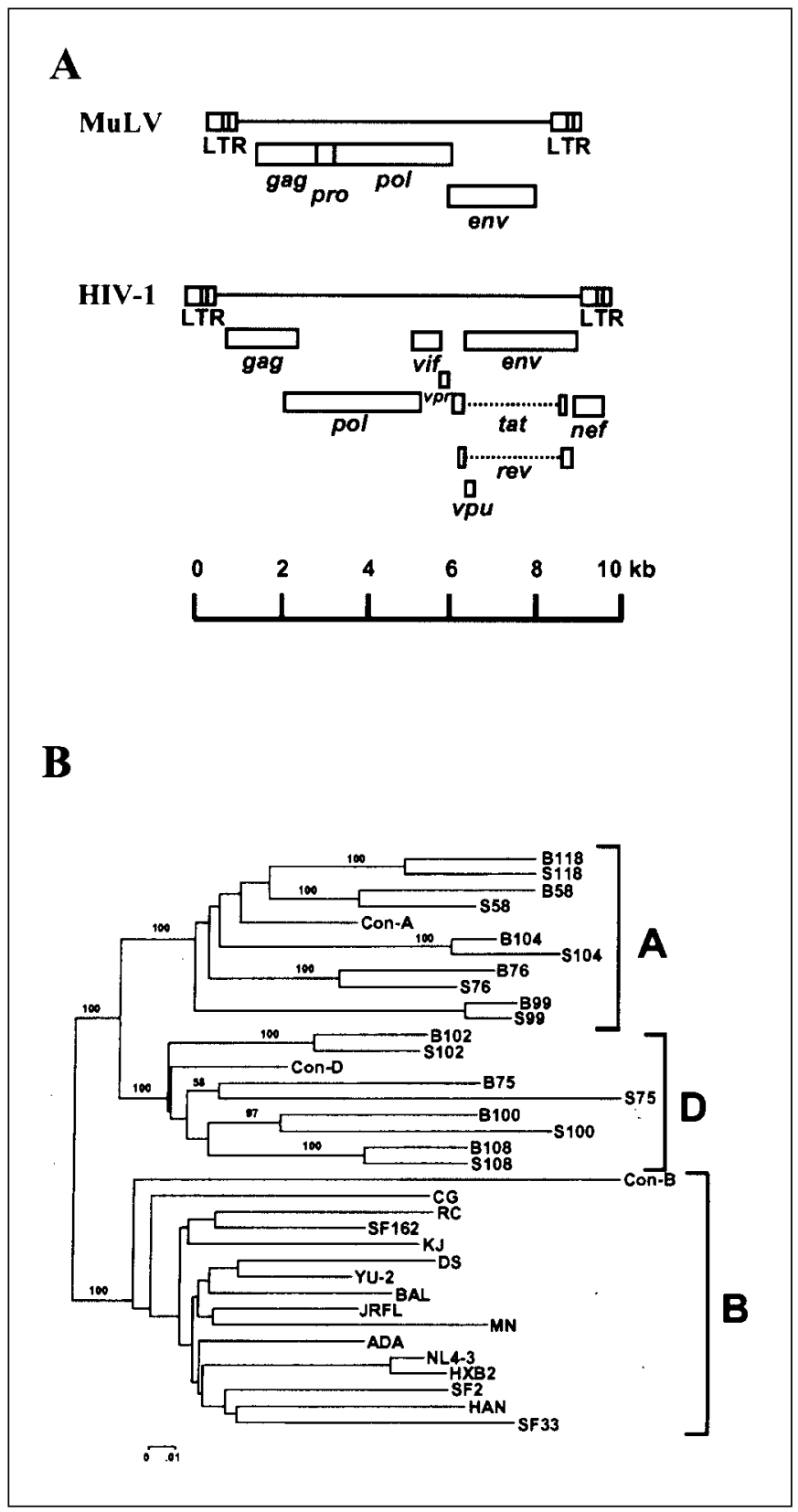

Figure 4: Genomic structure of HIV-1 and a murine retrovirus (MuLV) showing common genes (A). A phylogenetic tree showing clustering of different HIV-1 gp120 sequences from different patients (numbers) that is dependent on individual viral subtype (clade) $(B)$. B clade viruses are found predominantly in North America and Europe while $A$ and $D$ viruses are from East Africa. Brain- (B) and spleen- (S) derived sequences cluster within patients. Like blood-derived HIV-1, brainderived viruses also exhibit immense molecular heterogeneity between patients and clades $(B)$.

prevalence of peripheral neuropathies remains high. At present, there are two major groups of neuropathy observed among patients with HIV infection, which may overlap to some extent in clinical features and occurrence. ${ }^{34}$ The first group to be recognized was the HIV-associated neuropathies such as distal sensory polyneuropathy (DSP), acute and chronic demyelinating neuropathies, and mononeuritides multiplex. ${ }^{35}$ Distal sensory polyneuropathy is the most frequently encountered, affecting 35$45 \%$ of AIDS-defined patients, and is associated with advanced HIV infection and is usually manifested by chronic or subacute complaints of burning foot pain, paresthesiae, dysesthesiae, distal sensory loss with diminished or absent distal deep tendon reflexes. ${ }^{36}$ This neuropathy may improve with HAART although several antiretrovirals are clearly toxic to peripheral nerves. The second group of neuropathies, frequently encountered among treated HIV/AIDS patients, includes the toxic neuropathies (TN), arising due to the use of antiretrovirals including didanosine (DDI), zalcitabine (DDC), stavudine (D4T) and to a lesser extent, lamivudine (3TC). ${ }^{37}$ The symptoms and signs of toxic neuropathies are similar to DSP and the two entities are frequently indistinguishable except by history of recent onset neuropathy with initiation of a neurotoxic drug within several months. The pathological features of DSP and TN include distal "Wallerian" axonal degeneration of long fibers with small diameter sensory fibers being chiefly affected. Macrophage infiltration and activation is also frequently observed with detection of viral protein or nucleic acid in macrophages of 30$50 \%$ of biopsies. Similarly, inflammatory cells, including macrophages and lymphocytes, have been reported in the dorsal root ganglia (DRG) of AIDS patients with neuropathy, which may be accompanied by a decrease in the number of DRG neurons. Recent skin biopsy studies indicate a loss or degeneration of small diameter $\mathrm{C}$ and $\mathrm{A} \delta$ fibers in epidermis among HIV/AIDS patients with and without concurrent HAART, and fiber degeneration may precede symptoms and signs of neuropathy. ${ }^{38,39}$

\section{Virological Aspects}

HIV-1 belongs to the lentivirus genus of retroviruses, which are defined by a relatively slow disease course in their natural hosts. Other lentiviruses include visna-maedi virus, simian (SIV), feline (FIV), and bovine (BIV) immunodeficiency viruses, which are also neurotropic. ${ }^{40}$ HIV-2, which is chiefly found in West Africa and is genetically closely related to SIV, exhibits less systemic virulence but is of uncertain neurovirulence. Like all retroviruses, the HIV-1 genome is defined by gag, pol, and env genes, but HIV also contains several nonstructural genes that influence splicing and transcriptional events, for a total of 10 open reading frames within approximately 10 kilobase pairs ${ }^{41}$ (Figure 4A). Extensive variation within different HIV-1 strains is manifested both genotypically as well as phenotypically; ${ }^{42,43}$ this arises from poor fidelity during reverse transcription and recombination in the virion between the diploid RNA molecules (Figure 4B). Viral phenotypes have been defined in terms of cell tropism: most HIV strains are either macrophage- or T cell-tropic but dual tropic viruses have also been described. ${ }^{40,44}$ HIV-1 cell tropism is chiefly defined by which chemokine receptor the virus uses as a co-receptor; CXCR4 on $\mathrm{T}$ cells and CCR5 receptor on macrophages function together with the CD4, for infection; ${ }^{45}$ although viruses using CCR5 can be isolated from Tlymphocytes $^{46}$ (Figure 5). In addition, different HIV strains have also been defined in vitro as syncytia (SI)- or nonsyncytiainducing (NSI). ${ }^{47}$ 


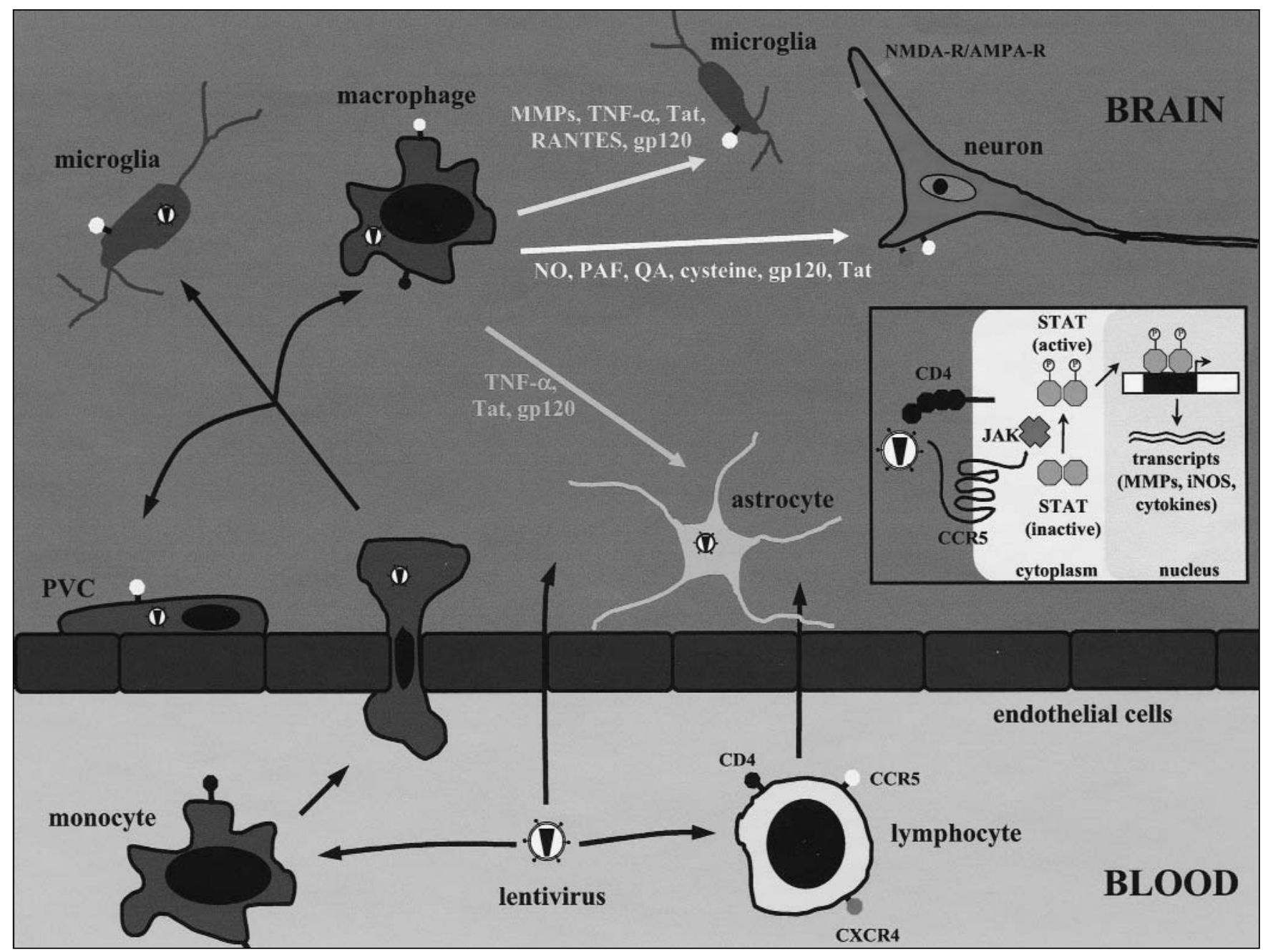

Figure 5: Potential mechanisms by which HIV-1 enters the nervous system and causes neuronal injury. Macrophages and lymphocytes, expressing CD4 and CCR5 or CXCR4 are infected in the periphery and subsequently traverse the blood-brain (or blood-nerve) barrier. Once in the nervous system, other cells of macrophage/microglia lineage are infected or are induced to release potential neurotoxins including cytokines, chemokines, matrix metalloproteinases, quinolinic acid, glutamate and nitric oxide. To a limited extent astrocytes are infected which also influence neuronal survival. The inset shows a potential signaling pathway in macrophage/microglia involving HIVgp120 induction of MMP expression through CCR5 and subsequent activation and nuclear translocation of the transcription factor, STAT-1 (after Power C. Trends in Neurosciences 2001;24:162-165, with permission from Elsevier Science).

\section{NEUROPATHOGENESIS}

Neurovirological infections are defined by the following attributes: neuroinvasiveness or ability of virus to enter the nervous system; neurotropism or ability of virus to infect brain cells (including the selective infection of neurons, termed neuronotropism) and neurovirulence or ability of virus to cause nervous system disease. ${ }^{48}$ HIV-1 fulfills each of the above criteria. Several properties that contribute to HIV's complex neurobiology include: (i) its predilection to genomic mutation, (ii) its induction of both innate and adaptive immune responses within the nervous system and (iii) its ability to cause disease simultaneously outside the nervous system. ${ }^{49}$

\section{Neuroinvasion}

Neuroinvasion by HIV-1 occurs early after initial (primary) infection and has occurred in most patients by the time of death. HIV antigens and/or genome have been detected in the brains of
HIV-infected patients at all stages of infection. ${ }^{50-52}$ Studies of patients who have died soon after infection of other causes exhibit viral antigen and neuropathological findings indicative of HIV infection. ${ }^{53}$ The mechanism by which HIV enters the CNS has been assumed to be infection of macrophages or lymphocytes, which cross the blood-brain barrier and infect cells of macrophage lineage (microglia and perivascular macrophages) in the brain. This has been termed the "Trojan Horse" hypothesis ${ }^{54}$ (Figure 5). An alternative pathway for entry into the CNS includes infiltration of the choroid plexus with subsequent seeding of the brain by infected macrophages or CD4 lymphocytes harbouring CCR5-using viral strains. . $^{55-58}$

The viruses recovered from the brains of AIDS and pre-AIDS patients are macrophage-tropic viruses in terms of viral gene sequence analyses and in vitro cell tropism. ${ }^{59-61}$ However, monocyte/macrophage traffic through the CNS is limited, unless some injury or infection has occurred within the brain. Several 
chemokines, including macrophage inflammatory protein (MIP)$1 \alpha$ and MCP-1, show enhanced expression in the brains of HIV infected patients suggesting that monocyte/macrophages (HIVinfected or uninfected) may be recruited into the CNS through a chemotactic mechanism. ${ }^{62}$ Additionally, upregulation of adhesion molecules such as intercellular adhesion molecule on the luminal aspect of brain endothelial cells has been demonstrated in vivo, which may facilitate monocyte/ macrophage adherence and subsequent CNS entry. ${ }^{63}$ Free virus may directly enter the CNS during initial plasma viremia; this route of entry has appeal because of the high levels of macrophage-tropic virus early in infection in the plasma and CSF. The relationship, if any, of CSF viral subtype and quantity to infection of the brain also remains unclear. ${ }^{64}$ As discussed below, viral load in CSF may be a predictor of severity of HIV dementia. ${ }^{65}$ How HIV enters the CNS remains a pivotal issue, because strategies to prevent CNS entry by HIV will be of value in preventing the development of neurological disease.

\section{Neurotropism}

HIV antigens and genome (DNA and RNA) in the brain are found primarily in microglia and perivascular macrophages ${ }^{66,67}$ and in astrocytes, albeit less frequently. ${ }^{68}$ Infected cells are principally localized in the central white matter and the deep gray matter structures including the basal ganglia. ${ }^{69}$ In situ hybridization, with and without PCR, confirms the immunocytochemical findings. ${ }^{68,70-72}$ To date, endothelia and oligodendrocytes have not been shown consistently to be infected in vivo although in vitro studies indicate these cell types are permissive to some strains of HIV-1. ${ }^{73-75}$ The question of in vivo infection of neurons remains controversial: Nuovo et $\mathrm{al}^{72}$ have reported detection of viral genome in neurons by in situ PCR and this finding has been confirmed by at least one other group. ${ }^{71}$ However, the preponderance of studies has failed to show viral nucleic acids in neurons. In vivo productive infection of neurons has not been shown to date, despite studies showing in vitro productive infection of neuronal cell lines. ${ }^{76,77}$

$\mathrm{HIV}$ infection is mediated by $\mathrm{CD} 4$ as the principal receptor on lymphocytes and macrophages..$^{42}$ However, CD4 expression is comparatively low in the brain although brain-derived strains of HIV utilize CD4 for infection. Several co-receptors have been shown to exist on blood-derived cells such as CCR5 on macrophages and CXCR4 on lymphocytes. ${ }^{78,79}$ Other coreceptors have been reported ${ }^{45}$ although their roles are less welldefined. In the brain, CCR5 and CCR3 have been postulated as potential co-receptors on microglia. ${ }^{80}$ Thus, HIV-1 strains isolated from brain appear to be principally macrophage-tropic ${ }^{59-}$ ${ }^{61}$ and have also been shown to infect microglia in vitro. ${ }^{81,82}$ The hypervariable V3 of HIV gp120 (Figure 4) derived from brain has been shown to be critical for HIV infection of macrophages and microglia. ${ }^{82,83}$ Recently, it has been demonstrated that brainderived HIV-1 V3 sequences mediate the use of CCR5 and CCR3, but not CXCR4, as co-receptors. ${ }^{84}$ Repeated passages of HIV in vitro can result in mutations in the envelope that resemble mutations identified in brain-derived sequences, suggesting that the virus may adapt to the brain. ${ }^{85}$ How the different regions of gp120 interact with plasma membrane receptors is uncertain but a conformationally dependent interaction between multiple regions of the envelope (V2, V3 and $\mathrm{C} 3$ regions) and the different receptors, has been proposed ${ }^{86,87} \mathrm{CXCR} 4$ has also been demonstrated on microglia, in addition to cells such as neurons. ${ }^{88}$ The failure of T-cell tropic (CXCR4-using) HIV-1 strains to establish productive infection of microglia, despite the presence of CXCR4, is enigmatic and may reflect a requirement for interaction between multiple co-receptors for infection or importance of replicative steps subsequent to attachment and penetration. Nonetheless, the role of this latter co-receptor in HIV neuropathogenesis remains intriguing because it may have important implications in mediating neuronal injury and death. ${ }^{89,90}$ Other HIV receptors in the brain have been reported, including galactosyl ceramide ${ }^{91}$ and a $260 \mathrm{Kd}$-astrocyte cell membrane protein..$^{92}$ Hence, the mechanisms of viral fusion and entry into brain cells remain uncertain and may differ from blood cells.

Cell tropism or infectivity of a retrovirus is determined by multiple viral genes that influence events during infection, including viral entry, reverse transcription, integration, transport of viral proteins and genome to the cell surface and budding of virions. ${ }^{42}$ Hence, several genes found within HIV are likely to influence its tropism. HIV entry appears to be modulated by different regions of gp120 that is encoded by the env gene..$^{93,94}$ Studies of other viral genes and their ability to influence neurotropism indicate that distinct $g a g^{95}$ and $t a t^{96}$ sequences may influence neurotropism but functional confirmatory studies are pending. Other groups using transgenic mice have shown that the HIV-1 LTR may be important for expression in the brain. ${ }^{97}$ Reverse transcriptase $\mathrm{e}^{98}$ and $e n v^{95}$ sequences from brain, blood and spleen cluster separately by phylogenetic analyses, suggesting that different organs may exert selective evolutionary pressures on viral replication and cell tropism within the organ. ${ }^{99}$

\section{Neurovirulence}

\section{(i) Viral strains}

The role of distinct lentivirus strains that do or do not cause neurological disease has remained controversial, largely because the immense molecular diversity within lentiviruses obscures discrete or specific viral sequences associated with disease. Nonetheless, evidence for virulent HIV-1 strains comes from several sources including (1) studies showing that specific HIV-1 subtypes (clades) are associated with an accelerated disease course compared to socio-economically and geographicallymatched patients infected with other HIV-1 clades; ${ }^{100}$ (2) the occurrence of drug resistant viral strains that are defined by specific mutations in the HIV-1 pol gene; ${ }^{101}$ (3) the use of CXCR4 by more pathogenic blood-derived viral species instead of CCR5 as disease progresses; ${ }^{102}$ (4) organ-specific compartmentalization of HIV-1 quasispecies. ${ }^{61,103}$ Evidence that individual viral strains play a direct or causative role in lentivirus-induced brain disease is derived from studies showing that distinct SIV and FIV strains are responsible for disease development in animal models. ${ }^{104-106}$ Additionally, specific sequences within the env gene have been shown to influence the development of animal lentivirus neurological disease..$^{107,108}$

In studies of a well-characterized, prospective cohort of AIDS patients with and without HAD, specific mutations within the V3 ${ }^{61}$ and V1 ${ }^{109}$ domains of brain-derived HIV-1 envelope sequences differed between AIDS patients with and without dementia. These findings are supported by subsequent studies. ${ }^{110,111}$ These same domains also determined the ability of 
Table 1: Potentially neurotoxic molecules implicated in HIV neuropathogenesis

\begin{tabular}{ll}
\hline $\begin{array}{c}\text { Source } \\
\text { Viral proteins }\end{array}$ & \multicolumn{1}{c}{ Molecules } \\
Tat, Nef, gp41, gp120, Vpr \\
Macrophage factors & Low molecular weight toxic factors: Ntox, \\
& Quinolinic acid, glutamate \\
& Arachidonic acid metabolites \\
& (prostaglandins $\mathrm{E}_{2}, \mathrm{~F}_{2 \alpha} ;$ thromboxane $\mathrm{B}_{2} ;$ \\
& platelet activating factor) \\
& Matrix metalloproteinases (MMP-2, MMP-7, \\
& MMP-9, TACE) and their substrates \\
& NO, super anion, peroxynitrite \\
& Cytokines: TNF- $\alpha$, IL-1 $\beta$, IL-6, IFN- $\alpha$ \\
& Chemokines: MCP-1, RANTES, MIP-1 $\alpha$, \\
& SDF-1 $\alpha$
\end{tabular}

IFN, interferon; IL, interleukin; TNF, tumor necrosis factor; MCP-1, monocyte chemoattractant protein-1; RANTES, regulated upon activation normal T cell suppressed and secreted; MIP-1 $\alpha$, macrophage inflammatory protein-1 $\alpha$; SDF, stromal derived factor

infectious recombinant clones to infect and spread in macrophage and mixed glial cultures; but these recombinants do not replicate in $\mathrm{T}$ cell analogue $(\mathrm{HeLa} / \mathrm{CD} 4)$ cultures. ${ }^{82}$ In addition, conditioned media from macrophages infected with recombinant viruses from HAD patients caused greater neuronal death when applied to human neural cultures. ${ }^{109}$ However, other studies have shown that T cell-tropic strains of HIV-1 induced the highest levels of neuronal injury when tested in an in vitro model of neuronal death, possibly through activation of CXCR4 expressed on neurons. ${ }^{112}$ Recent studies confirm the findings that brain-derived viruses use chiefly CCR5 and differ between patients with and without HAD, although the region of brain from which the virus was isolated may influence its replicative properties. ${ }^{110,111}$

\section{(ii) Viral proteins}

There is extensive literature implicating several different virus-encoded proteins in HIV-1 neuropathogenesis. ${ }^{113} \mathrm{HIV}-1$ $e n v$-encoded gp120 has been shown to be directly and indirectly neurotoxic in vitro and in vivo ${ }^{114-116}$ (Table 1). Specific domains within gp120 have been implicated as especially neuropathogenic, including the CD4 binding ${ }^{117}$ and the V3 regions. ${ }^{118}$ One proposed mechanism is the accumulation of intracellular calcium in neurons following activation of glutamate receptors and voltage-operated calcium channels. ${ }^{119}$ For example, indirect activation of the N-methyl D-aspartate (NMDA) receptor may result in neuronal death, through binding to the adjacent glycine receptor or increased free zinc concentrations. ${ }^{120}$ This binding can be blocked with several different NMDA receptor antagonists such as memantine and AP5. ${ }^{121}$ Other neurotransmitters may be affected by gp120induced activation of NMDA receptors, such as impaired dopamine transport shown in dopaminergic neurons cultured from rat midbrain. ${ }^{122}$ Dawson et al ${ }^{123}$ have also shown that nitric oxide may modulate gp120 neurotoxicity. Transgenic mice expressing HIV-1 gp120 in astrocytes display neuropathological findings including astrogliosis, neuronal loss, and dendritic vacuolizations, resembling HIV encephalitis. ${ }^{124}$ Studies of gp120 action on glial cells suggest that the protein may alter glial function through pertubation of the $\mathrm{Na}^{+} / \mathrm{H}^{+}$ion transporter(s) in astrocytes; this in turn might contribute to neuronal dysfunction and death. ${ }^{125}$ It has also been shown that gp120 affects intracellular signaling that controls the expression of different cell adhesion molecules, cytokines and perhaps nitric oxide through the JAK-STAT pathway. ${ }^{126}$ Recent studies suggest that mutations in gp120 may influence the induction of matrix metalloproteinases (MMP) by mechanism involving STAT-1 in macrophages ${ }^{108}$ (Figure 5, inset). The above in vitro and in vivo findings support the hypothesis that gp120 is directly involved in the pathogenesis of HIV-induced neurological injury.

Other HIV proteins including Tat, gp41, and Nef have been shown to be neurotoxic in vitro. ${ }^{127,128}$ The transactivating protein, Tat, has attracted extensive attention in neuropathogenesis studies because early studies showed it was neurotoxic, released from infected lymphocytes, was taken up by cells and could, in turn, transactivate host genes such as TNF- $\alpha{ }^{129}$ and IL-1. ${ }^{130}$ As with gp120, several domains within tat have been found to be especially neurotoxic including the basic region and the RGD amino acid residues in the second exon, but other groups have shown that the entire first exon is necessary for neurotoxicity. Conant and colleagues have shown that Tat induces the expression of MCP-1 in astrocytes, which may influence macrophage trafficking in the CNS. ${ }^{131}$ Our group has recently shown that brain-derived tat sequences induce the expression of MMP-2, which is neurotoxic in vitro and in vivo. ${ }^{132}$

\section{(iii) Viral load}

Many studies indicate that viral replication in blood is extremely high in persons with HIV-1 infection and the balance established between viral replication and clearance shown in the viral load set point is predictive of the course of systemic disease. ${ }^{133}$ However, the role of viral load in brain in relation to the development of neurological disease is less clear. Viral load in CSF is usually several orders of magnitude less than plasma and is correlated to some extent with the presence of HAD. ${ }^{134} \mathrm{In}$ addition, the source of virus in CSF may be derived from both blood and brain. ${ }^{135}$ Differing results depending on the method of viral or proviral quantitation have been reported from various groups examining the relationship between viral load in the CNS and in the development of HIV dementia. QC-PCR studies of brain-derived viral mRNA and proviral DNA in brain indicate no significant difference in levels between AIDS patients with and without HIV dementia. ${ }^{136,137}$ In contrast, viral protein and RNA levels detected in CSF, ${ }^{138}$ and viral antigen load, as detected by immunocytochemistry in brain, ${ }^{26,139}$ show elevated levels among patients with HAD compared to nondemented AIDS controls. Other studies suggest that CSF viral load is correlated with neuropsychological abnormalities ${ }^{134}$ but is one hundred-fold less than that of plasma viral load. ${ }^{64}$ Viral load in the brain measured by immunostaining or quantitative molecular methods is closely associated with the extent of pathological change accompanying HIV encephalitis. ${ }^{140}$ 


\section{(iv) Neuroinflammation}

Excess production of host-encoded inflammatory molecules by microglia and perhaps astrocytes has been proposed as a chief cause of damage within the brain in a number of diseases including Alzheimer's disease, stroke, multiple sclerosis and HAD. ${ }^{141}$ This hypothesis is predicated on data derived from cell culture experiments, animal models and studies of autopsy tissues. Among studies of HIV neuropathogenesis, this hypothesis has gained wide popularity because microglia and astrocytes are the principal cells infected or activated by HIV-1, resulting in the release of inflammatory and neurotoxic molecules (Table 1, Figure 4).

In 1990, Giulian and colleagues ${ }^{142}$ showed that HIV-infected monocytoid cell lines secreted diffusible molecules that killed several different neuronal cell types by a presumed excitotoxic mechanism, mediated by NMDA receptors. Pulliam et al ${ }^{143}$ also reported that HIV-infected macrophages produced a neurotoxic compound(s) causing cytopathic effects in cultured cell aggregates from human fetal brain tissue. In contrast, other groups $^{144}$ have shown that only following direct contact with neurons in vitro, could HIV-infected monocytes induce neurotoxicity although a soluble neurotoxin could not be demonstrated. Despite the controversy surrounding this area, several potential neurotoxins have been identified and characterized in vitro and in vivo. ${ }^{145}$

Multiple cytokines have been shown to be elevated in the brains and CSF of patients with HIV dementia, ${ }^{146-148}$ which include tumor necrosis factor-alpha (TNF- $\alpha$ ), interleukin-1 (IL1), interleukin-6 (IL-6) and tissue growth factor-beta (TGF- $\beta$ ). Although most cells in the CNS can produce cytokines, the chief sources of these small-secreted proteins are activated glial cells that include macrophages, microglia and astrocytes. TNF- $\alpha$ is an inflammatory cytokine that has received extensive attention for its potential neurotoxic effects in HIV infection and ability to influence the release of other cytokines. ${ }^{149} \mathrm{TNF}-\alpha$ is released by microglia and astrocytes ${ }^{146,150}$ in HIV infection and can prevent uptake of glutamate ${ }^{151}$ and may be directly toxic to neurons. ${ }^{152}$ Several studies have shown that TNF- $\alpha$ mRNA and protein levels are increased in the brains and CSF of patients with HIV infection. Notably, Wesselingh et $\mathrm{al}^{147}$ showed that TNF- $\alpha$ mRNA levels were increased in brains of patients with HIV dementia compared to AIDS patients without dementia or noninfected controls; furthermore, the level of mRNA was correlated with the severity of dementia. Il-6 has also been reported to be increased in the brains of patients with HIV infection ${ }^{146,153}$ and may mediate neurotoxicity indirectly. TGF- $\beta$ and nerve growth factor (NGF) have been reported to be overexpressed in HIVinfected brain. ${ }^{154}$ The latter molecules have neurotrophic properties and, hence, their increased production may reflect a host defense response to the neurotoxic actions of HIV.

Cells of macrophage lineage also produce arachidonic acid and its metabolites. ${ }^{155}$ Griffin et al ${ }^{156}$ reported that prostaglandin $\mathrm{E}_{2}$ and $\mathrm{F}_{2 \alpha}$ and thromboxane $\mathrm{B}_{2}$ were elevated in CSF from patients with HAD, compared to patients without dementia. Other groups have shown elevated levels of arachidonic acid metabolites including platelet-activating factor (PAF) in HIVinfected macrophages although most of the products were produced through the lipoxygenase pathway. ${ }^{157}$ It may be that arachidonic acid metabolites influence neurotoxicity indirectly by regulating the expression of glutamate uptake by astrocytes, as has been shown in vitro. ${ }^{158}$ Quinolinic acid (QA), a metabolite of tryptophan metabolism, is produced by macrophages following different types of stimulation. ${ }^{159}$ By binding to NMDA receptors, QA has been shown to have neurotoxic properties following acute or chronic exposure. ${ }^{160}$ QA levels in CSF appear to correlate with the severity of dementia. ${ }^{161,162}$ Increased MMP expression has been shown in several in vitro and in vivo studies following HIV infection ${ }^{108,132,163}$ and is associated with neurological disease. ${ }^{164}$ Likewise, increased levels of inducible nitric oxide synthase have been reported in the brains of patients with severe $\mathrm{HAD}$, implicating nitric oxide as a potential neurotoxin. ${ }^{165,166}$ The inducible nitric oxide synthase levels also correlated with the levels of HIV gp41 expression in brain. ${ }^{127}$ An intriguing report described a novel neurotoxin, Ntox, which is released by activated microglial cells, although full characterization of the molecule is pending. ${ }^{167}$

With the increased understanding in the role of chemokine receptors as co-receptors for HIV infection, a concomitant expanding interest has developed in the actions of chemokines in the nervous system in the context of HIV infection and other neurological diseases. ${ }^{168}$ Several chemokines are increased in the CSF and brains of patients with HIV infection, ${ }^{62,88,169}$ including MIP- $1 \alpha$ and MIP-1 $\beta$, regulated upon activation normal $\mathrm{T}$ cell suppressed and secreted (RANTES) and inflammatory protein10. Other groups have shown that monocyte chemoattractant protein-1 (MCP-1) levels are increased in the CSF and brains of patients with HIV dementia ${ }^{131}$ while in vitro studies suggest that stromal derived factor- 1 is neurotoxic. ${ }^{131 a}$ The exact role of these chemokines remains uncertain because several groups have shown that MIP-1 $\alpha$ and RANTES are able to block gp120induced neuronal death. ${ }^{90}$ Complementary studies show that different chemokines affect calcium signaling in neurons and demonstrate that chemokine receptors, which have shown to be expressed on neurons, may directly influence neuronal survival. ${ }^{170}$

\section{(v) Host susceptibility}

Although multiple host molecules have been implicated in the inflammatory cascade of events causing HIV-associated neuronal and axonal injury, there have been few specific polymorphisms or mutations identified in genes associated with these molecules. However, the APOE E4 allele has been associated with an increased likelihood of developing HAD in one study ${ }^{171}$ and a recent study suggested that a polymorphism in TNF- $\alpha$ was associated with an increased risk of HAD. ${ }^{171 a}$ Two small studies have shown that a deletion in the CCR5 gene among heterozygotes is accompanied by a lower frequency of HAD occurrence. ${ }^{172,173}$ This latter finding complements other studies showing that CCR5 mediates both HIV infection and intracellular signaling ${ }^{174}$ pathways involved in inflammation. Clinical studies have reported slower progression of systemic disease among HIV-infection patients carrying the CCR5 deletion. ${ }^{175}$

\section{(v) Neuronal damage}

There is increasing interest and understanding of the intracellular signaling pathways and mechanisms by which neurons are damaged and/or killed during ontogeny and disease. ${ }^{176}$ In the context of HIV infection, these questions are 
just beginning to be addressed. Studies of autopsy tissues indicate several distinctive patterns of neuronal loss, ${ }^{30,177,178}$ including a reduction in neuronal cell body volume in the frontal cortices of patients. ${ }^{179,180}$ Diminished dendritic arborization and loss of presynaptic terminals have also been reported in the brains of HIV-infected individuals, which may reflect a retrograde phenomenon of white matter injury in some instances. $^{31}$ Select neuronal sub-populations, including larger pyramidal cells within the cortex identified by stereological methods, are at greater risk of cell death and similarly neuronal populations defined by expression of certain neurotransmitters such as GABA or proteins, including parvalbumin and calbindin, are more likely to be diminished in HIV-infected brains. ${ }^{30}$ Synaptic density is diminished in patients with HIV-induced cognitive impairment. ${ }^{180}$ In contrast, other neuronal populations expressing neuropeptides such as somatostatin appear relatively resistant to HIV-induced injury. ${ }^{181}$ In some studies, the mechanism of cell death has been shown to be apoptotic, ${ }^{182,183}$ although this was not correlated with the occurrence of dementia. ${ }^{184}$ However, it is unclear at present if programmed cell death is the major mechanism of neuronal loss, nor is it apparent the extent to which glia die during the course of HIV infection of the brain, ${ }^{185}$ although a recent study indicated that HAD patients with rapid progression exhibited increased levels of astrocyte cell death. ${ }^{185 a}$ In vitro studies have implicated different intracellular signaling pathways in neurons as potential routes to cell death. For example, gp120 induces apoptosis in human fetal neurons through the activation of JNK and ERK pathways. ${ }^{186}$ Other studies suggest that gp120, derived from a T-cell tropic HIV strain, induced neuronal apoptosis that was mediated by p38 mitogen activated protein kinase. ${ }^{90}$ In vitro studies using HIV-1 tat indicate that the glycogen synthase kinase- 3 beta and caspase 9 are also involved in neuronal death. ${ }^{187}$ Thus, these studies indicate that multiple pathways may determine the mechanism and frequency of HIV-related neuronal death.

\section{THERAPEUTIC CONSIDERATIONS}

The availability of HAART has revolutionized the care of patients with HIV infection in developed countries. Survival times have lengthened, and both general health and quality of life have been improved. HAART is usually comprised of three or more antiretroviral drugs including, most often, two nucleoside analogues and either a non-nucleoside reverse transcriptase inhibitor or an HIV viral protease inhibitor (Table 2). Signs and symptoms of HIV-related cognitive impairment, VM and DSP are actually improved with HAART, although the pre-treatment level of impairment often limits the extent of recovery. ${ }^{188-193}$ Two main mechanisms may contribute to the improvement in neurological disability. Direct inhibition of viral replication in the CNS is one mechanism proposed despite the limited CNS penetration by many antiretroviral drugs such as the large molecule protease inhibitors. Reduced seeding of the CNS by HIV-1 from the periphery because of reduced plasma levels of viremia is a second mechanism. ${ }^{12}$ A third potential mechanism includes improved systemic immune function with accompanying enhanced regulation of macrophage function, perhaps resulting in diminished neuroinflammation. However, in patients with HAD the addition of a single antiretroviral
Table 2: Therapeutics for HIV-related neurological disorders

\section{Drug - type}

A) Antiretroviral therapies:

Nucleoside analogues:

(AZT, 3TC, dT4, abacavir, DDI ${ }^{1}, \mathrm{DDC}^{1}$ ) HAD/MCMD, DSP

Protease inhibitors:

indinavir, ritonavir, nelfinavir,

lopinavir, amprenavir

HAD/MCMD, DSP

Non-nucleoside RT inhibitors:

efavirenz, nevaripine

B) Neuroprotective therapies:

OPC 14117 - antioxidant

nimodipine - calcium channel blocker

selegiline (deprenyl) - antioxidant

lexipafant - anti-PAF

Neurological syndrome

memantine ${ }^{2}$ - NMDA receptor antagonist HAD

$\mathrm{CN} 1189^{2}$ - anti-TNF $\alpha$

NGF - neurotrophin

HAD/MCMD

HAD

HAD/MCMD

$\mathrm{HAD} / \mathrm{MCMD}$

HAD

DSP/TN

\section{C) Symptomatic therapies:}

Gabapentin DSP/TN

Tegretol DSP/TN

Tricyclic antidepressants $\quad$ DSP/TN

Amantadine/L-DOPA Parkinsonism/HAD

${ }^{1}$ DDI and DDC are highly associated with the development of TN.

2 Trials in progress.

$\mathrm{AZT}=$ zidovudine $; \mathrm{DDI}=$ didanosine $; \mathrm{DDC}=$ zalcitabine $; 3 \mathrm{TC}=$ lamivudine; $\mathrm{D} 4 \mathrm{~T}$ = stavudine $; \mathrm{RT}=$ reverse transcriptase $\mathrm{PAF}=$ platelet activating factor

nucleoside analogue, abacavir, failed to confer any improvement in cognition, probably due to pre-existing drug resistance mutations. ${ }^{194}$ Antiretroviral resistance mutations in the reverse transcriptase and protease encoding genes have been identified in viruses from patients who show high viral loads in blood despite HAART. ${ }^{195,196}$ The extent to which these mutations are present in the viruses found in the brains of patients treated with antiretroviral drugs is unknown. Brain-derived viruses exhibit fewer mutations associated with drug-resistance than matched blood-derived HIV isolates. This may reflect poor CNS drug penetration and/or limited replication in the brain, which would diminish the potential for drug resistant mutations to emerge but may also simply reflect sampling artifact. ${ }^{98,197}$

Neuroprotective strategies have also been employed for both neurocognitive impairment and peripheral neuropathy in HIV-1 infection. A recent randomized clinical trial (RCT) showed that NGF was beneficial in terms of reducing symptoms related to DSP and TN. ${ }^{198}$ The antioxidant, selegiline (deprenyl) has been shown to improve neuropsychological performance in patients with HIV-related neurocognitive impairment in a small $\mathrm{RCT}^{13}$ and this preliminary finding has led to the design of a larger trial. Lexipafant, an antagonist of the putative neurotoxin, PAF, 
showed a trend towards improvement in HIV-related neurocognitive impairment in a small RCT. ${ }^{199}$ Likewise, an antioxidant, OPC- $14117^{13}$ and the calcium channel blocker, nimodipine $^{200}$ showed beneficial trends in small RCT. Several trials are in progress testing compounds including a NMDA antagonist, memantine, and a TNF- $\alpha$ inhibitor, CN-1189.

\section{FUTURE ISSUES}

Although the AIDS epidemic continues to expand with ever increasing numbers of infected individuals, many important questions remain unanswered regarding the pathogenesis and optimal treatment of HIV-related neurological disorders. The potential role of the brain as a protected viral reservoir for drug resistant strains of virus or as a reservoir that can re-seed the systemic circulation after the virus has been eradicated in other sites is not resolved. Most HIV neuropathogenesis studies using human samples performed to date have focused on gay males infected with clade B viruses from North American and Europe. The extent to which this population sample reflects the entire spectrum of the neuropathogenesis of HIV-1 is uncertain. Finally, the exact function(s) and regulation of the plethora of inflammatory molecules released by macrophages infected by or exposed to HIV have yet to be defined. This latter question is of interest because it may provide valuable insights into the mechanisms of neuronal injury mediated by HIV infection. At the same time, understanding the role(s) of these inflammatory molecules will provide clues to the pathogenesis and rational therapy of other neurological diseases characterized by glial activation and neuronal damage.

\section{ACKNOWLEDGEMENTS}

The authors thank B. Ibrahim for assistance with manuscript preparation. CP is an Alberta Heritage Foundation for Medical Research Scholar.

\section{REFERENCES}

1. Nicoll A, Gill ON. The global impact of HIV infection and disease. Commun Dis Public Health 1999; 2: 85-95.

2. Johnson R. Viral Infections of the Nervous System. 2nd Ed. Philadelphia: Lippincott-Raven Publishers, 1998.

3. Power C, Johnson RT. HIV-1 associated dementia: clinical features and pathogenesis. Can J Neurol Sci 1995; 22: 92-100.

4. McArthur JC. Neurologic manifestations of AIDS. Medicine (Baltimore) 1987; 66: 407-437.

5. McArthur JC, Hoover DR, Bacellar H, et al. Dementia in AIDS patients: incidence and risk factors. Multicenter AIDS Cohort Study. Neurology 1993; 43: 2245-2252.

6. White DA, Heaton RK, Monsch AU. Neuropsychological studies of asymptomatic human immunodeficiency virus- type-1 infected individuals. The HNRC Group. HIV Neurobehavioral Research Center. J Int Neuropsychol Soc 1995; 1: 304-315.

7. Janssen R. Nomenclature and research case definitions for neurologic manifestations of human immunodeficiency virustype 1 (HIV-1) infection. Report of a Working Group of the American Academy of Neurology AIDS Task Force. Neurology 1991; 41: 778-785.

8. Navia BA, Jordan BD, Price RW. The AIDS dementia complex: I. Clinical features. Ann Neurol 1986; 19: 517-524.

9. Mirsattari SM, Power C, Nath A. Parkinsonism with HIV infection. Mov Disord 1998; 13: 684-689.

10. Maher J, Choudhri S, Halliday W, et al. AIDS dementia complex with generalized myoclonus. Mov Disord 1997; 12: 593-597.

11. Childs EA, Lyles RH, Selnes OA, et al. Plasma viral load and CD4 lymphocytes predict HIV-associated dementia and sensory neuropathy. Neurology 1999; 52: 607-613.

12. Sacktor N, Lyles RH, Skolasky R, et al. HIV-associated neurologic disease incidence changes: Multicenter AIDS Cohort Study, 1990-1998. Neurology 2001; 56: 257-260.

13. A randomized, double-blind, placebo-controlled trial of deprenyl and thioctic acid in human immunodeficiency virus-associated cognitive impairment. Dana Consortium on the Therapy of HIV Dementia and Related Cognitive Disorders. Neurology 1998; 50: 645-651.

14. Ellis RJ, Deutsch R, Heaton RK, et al. Neurocognitive impairment is an independent risk factor for death in HIV infection. San Diego HIV Neurobehavioral Research Center Group. Arch Neurol 1997; 54: 416-424.

15. Simpson DM, Tagliati M. Neurologic manifestations of HIV infection [published erratum appears in Ann Intern Med 1995 Feb 15;122(4):317]. Ann Intern Med 1994; 121: 769-785.

16. Dal Pan GJ, McArthur JH, Aylward E, et al. Patterns of cerebral atrophy in HIV-1-infected individuals: results of a quantitative MRI analysis. Neurology 1992; 42: 2125-2130.

17. Chang L, Ernst T, Leonido-Yee M, et al. Cerebral metabolite abnormalities correlate with clinical severity of HIV-1 cognitive motor complex. Neurology 1999; 52: 100-108.

18. Navia BA, Cho ES, Petito CK, et al. The AIDS dementia complex: II. Neuropathology. Ann Neurol 1986; 19: 525-535.

19. Sharer LR. Pathology of HIV-1 infection of the central nervous system. A review. J Neuropathol Exp Neurol 1992; 51: 3-11.

20. Vinters HA, Anders KH. Neuropathology of AIDS. CRC Press, Inc. Boca Raton, Florida, 1990.

21. Glass M, Faull RL, Bullock JY, et al. Loss of A1 adenosine receptors in human temporal lobe epilepsy. Brain Res 1996; 710: 56-68.

22. Sharer LR, Epstein LG, Cho ES, et al. Pathologic features of AIDS encephalopathy in children: evidence for LAV/HTLV-III infection of brain. Hum Pathol 1986; 17: 271-284.

23. Petito CK, Cash KS. Blood-brain barrier abnormalities in the acquired immunodeficiency syndrome: immunohistochemical localization of serum proteins in postmortem brain. Ann Neurol 1992; 32: 658-666.

24. Power C, Kong PA, Crawford TO, et al. Cerebral white matter changes in acquired immunodeficiency syndrome dementia: alterations of the blood-brain barrier. Ann Neurol 1993; 34: 339350 .

25. Shi BD, De Girolami U, He, J; et al, Apoptosis induced by HIV-1 infection of the central nervous system. J Clin Invest 1996; 98: 1979-1990.

26. Glass JD, Fedor H, Wesselingh SL, et al. Immunocytochemical quantitation of human immunodeficiency virus in the brain: correlations with dementia. Ann Neurol 1995; 38: 755-762.

27. Rostasy K, Monti L, Yiannoutsos C, et al. NFkappaB activation, TNF-alpha expression, and apoptosis in the AIDS- DementiaComplex. J Neurovirol 2000; 6: 537-543.

28. Achim CL, Heyes MP, Wiley CA. Quantitation of human immunodeficiency virus, immune activation factors, and quinolinic acid in AIDS brains. J Clin Invest 1993; 91: 27692775.

29. Everall IP, Luthert PJ, Lantos PL. Neuronal loss in the frontal cortex in HIV infection. Lancet 1991; 337: 1119-1121.

30. Masliah E, Ge N, Achim CL, et al. Selective neuronal vulnerability in HIV encephalitis. J Neuropathol Exp Neurol 1992; 51: 585593.

31. Masliah E, Ge N, Morey M, et al. Cortical dendritic pathology in human immunodeficiency virus encephalitis. Lab Invest 1992; 66: 285-291.

32. Dal Pan GB, Berger JR. Spinal Cord Disease in Human Immunodeficiency Virus Infection. In: Berger, J. L. RM AIDS and the Nervous System. 2nd Ed. Philadelphia: LippincottRaven Publishers, 1997:173-187.

33. DiRocco L, Dalton T, Liang D, et al. Nonallelism for the audiogenic seizure prone (Asp1) and the aryl hydrocarbon receptor (Ahr) loci in mice. J Neurogenet 1998; 12: 191-203.

34. Fuller GN, Jacobs JM, Guiloff RJ. Nature and incidence of 
peripheral nerve syndromes in HIV infection. J Neurol Neurosurg Psychiatry 1993; 56: 372-381.

35. Brannagan TM, McAlarneyT, Latov N, Peripheral neuropathy in HIV-1 infection. In: Latov, N. W. JH; Kelly, JJ. Immunological and Infectious Diseases of the Peripheral Nerves. Cambridge: Cambridge University Press, 1998:285-307.

36. Price RW. Neurological complications of HIV infection. Lancet 1996; 348: 445-452.

37. Dalakas MC, Cupler EJ. Neuropathies in HIV infection. Baillieres Clin Neurol 1996; 5: 199-218.

38. McCarthy BG, Hsieh ST, Stocks A, et al. Cutaneous innervation in sensory neuropathies: evaluation by skin biopsy. Neurology 1995; 45: 1848-1855.

39. Herrmann DN, Griffin JW, Hauer P, et al. Epidermal nerve fiber density and sural nerve morphometry in peripheral neuropathies. Neurology 1999; 53: 1634-1640.

40. Power C, Johnson RT. Neurovirological and neuroimmunological aspects of HIV infection. Adv Virus Res 2001; 56: 579-624.

41. Greene WC. The molecular biology of human immunodeficiency virus type 1 infection. N Engl J Med 1991; 324: 308-317.

42. Levy J. HIV and the Pathogenesis of AIDS. Second Ed. American Society of Microbiology. Washington. DC, 1998.

43. Korber B, Foley B, Leitner T, et al. Human retroviruses and AIDS. A compilation and analysis of nucleic acid and amino acid sequences. Theoretical Biology and Biophysics. Group T-10. Los Alamos: Los Alamos National Library 1997.

44. Collman R, Balliet JW, Gregory SA, et al. An infectious molecular clone of an unusual macrophage-tropic and highly cytopathic strain of human immunodeficiency virus type 1. J Virol 1992; 66: 7517-7521.

45. Deng H, Liu R, Ellmeier W, et al. Identification of a major coreceptor for primary isolates of HIV-1. Nature 1996; 381: 661666.

46. Pierson T, McArthur J, Siliciano RF. Reservoirs for HIV-1: mechanisms for viral persistence in the presence of antiviral immune responses and antiretroviral therapy. Annu Rev Immunol 2000; 18: 665-708.

47. Koot M, Vos AH, Keet RP, et al. HIV-1 biological phenotype in long-term infected individuals evaluated with an MT-2 cocultivation assay. AIDS 1992; 6: 49-54.

48. Johnson R. Possible viral cause of multiple sclerosis. In: Viral Infections of the Nervous System. 2nd Ed. Philadelphia: Lippincott-Raven, 1998:248-258.

49. Power C. Retroviral diseases of the nervous system: pathogenic host response or viral gene-mediated neurovirulence? Trends Neurosci 2001; 24: 162-169.

50. Koyanagi Y, Miles S, Mitsuyasu RT, et al. Dual infection of the central nervous system by AIDS viruses with distinct cellular tropisms. Science 1987; 236: 819-822.

51. Bell JE, Busuttil A, Ironside JW, et al. Human immunodeficiency virus and the brain: investigation of virus load and neuropathologic changes in pre-AIDS subjects. J Infect Dis 1993; 168: 818-824.

52. Budka H. Neuropathology of human immunodeficiency virus infection. Brain Pathol 1991; 1: 163-175.

53. Davis TH, Morton CC, Miller-Cassman R, et al. Hodgkin's disease, lymphomatoid papulosis, and cutaneous T-cell lymphoma derived from a common T-cell clone. N Engl J Med 1992; 326: $1115-1122$.

54. Haase AT. Pathogenesis of lentivirus infections. Nature 1986; 322: 130-136.

55. Falangola MF, Hanly A, Galvao-Castro B, et al. HIV infection of human choroid plexus: a possible mechanism of viral entry into the CNS. J Neuropathol Exp Neurol 1995; 54: 497-503.

56. Chun TW, Fauci AS. Latent reservoirs of HIV: obstacles to the eradication of virus. Proc Natl Acad Sci USA 1999; 96: 1095810961.

57. Chen H, Wood C, Petito CK. Comparisons of HIV-1 viral sequences in brain, choroid plexus and spleen: Potential role of choroid plexus in the pathogenesis of HIV encephalitis. J Neurovirol 2000; 6: 498-506.

58. Pierson T, Hoffman TL, Blankson J, et al. Characterization of chemokine receptor utilization of viruses in the latent reservoir for human immunodeficiency virus type 1 . J Virol 2000; 74: 7824-7833.

59. Cheng-Mayer C, Weiss C, Seto D, et al. Isolates of human immunodeficiency virus type 1 from the brain may constitute a special group of the AIDS virus. Proc Natl Acad Sci U S A 1989; 86: 8575-8579.

60. Reddy RT, Achim CL, Sirko DA, et al. Sequence analysis of the V3 loop in brain and spleen of patients with HIV encephalitis. AIDS Res Hum Retroviruses 1996; 12: 477-482.

61. Power C, McArthur JC, Johnson RT, et al. Demented and nondemented patients with AIDS differ in brain-derived human immunodeficiency virus type 1 envelope sequences. J Virol 1994; 68: 4643-4649.

62. Letendre SL, Lanier ER, McCutchan JA. Cerebrospinal fluid beta chemokine concentrations in neurocognitively impaired individuals infected with human immunodeficiency virus type 1 . J Infect Dis 1999; 180: 310-319.

63. Hurwitz AA, Berman JW, Lyman WD. The role of the blood-brain barrier in HIV infection of the central nervous system. Adv Neuroimmunol 1994; 4: 249-256.

64. McArthur JC, McClernon DR, Cronin MF, et al. Relationship between human immunodeficiency virus-associated dementia and viral load in cerebrospinal fluid and brain. Ann Neurol 1997; 42: 689-698.

65. Brew BJ, Pemberton L, Cunningham P, et al. Levels of human immunodeficiency virus type 1 RNA in cerebrospinal fluid correlate with AIDS dementia stage. J Infect Dis 1997; 175: $963-$ 966.

66. Koenig S, Gendelman HE, Orenstein JM, et al. Detection of AIDS virus in macrophages in brain tissue from AIDS patients with encephalopathy. Science 1986; 233: 1089-1093.

67. Wiley CA, Schrier RD, Nelson JA, et al. Cellular localization of human immunodeficiency virus infection within the brains of acquired immune deficiency syndrome patients. Proc Natl Acad Sci U S A 1986; 83: 7089-7093.

68. Takahashi K, Wesselingh SL, Griffin DE, et al. Localization of HIV-1 in human brain using polymerase chain reaction/in situ hybridization and immunocytochemistry. Ann Neurol 1996; 39: 705-711.

69. Kure K, Weidenheim KM, Lyman WD, et al. Morphology and distribution of HIV-1 gp41-positive microglia in subacute AIDS encephalitis. Pattern of involvement resembling a multisystem degeneration. Acta Neuropathol 1990; 80: 393-400.

70. Shaw GM, Harper ME, Hahn BH, et al. HTLV-III infection in brains of children and adults with AIDS encephalopathy. Science 1985; 227: 177-182.

71. Bagasra O, Lavi E, Bobroski L, et al. Cellular reservoirs of HIV-1 in the central nervous system of infected individuals: identification by the combination of in situ polymerase chain reaction and immunohistochemistry. AIDS 1996; 10: 573-585.

72. Nuovo GJ, Gallery F, MacConnell P, et al. In situ detection of polymerase chain reaction-amplified HIV-1 nucleic acids and tumor necrosis factor-alpha RNA in the central nervous system. Am J Pathol 1994; 144: 659-666.

73. Moses AV, Bloom FE, Pauza CD, et al. Human immunodeficiency virus infection of human brain capillary endothelial cells occurs via a CD4/galactosylceramide-independent mechanism. Proc Natl Acad Sci U S A 1993; 90: 10474-10478.

74. Poland SD, Rice GP, Dekaban GA. HIV-1 infection of human brain-derived microvascular endothelial cells in vitro. J Acquir Immune Defic Syndr Hum Retrovirol 1995; 8: 437-445.

75. Gyorkey F, Melnick JL, Gyorkey P. Human immunodeficiency virus in brain biopsies of patients with AIDS and progressive encephalopathy. J Infect Dis 1987; 155: 870-876.

76. Obregon E, Punzon C, Fernandez-Cruz E, et al. HIV-1 infection induces differentiation of immature neural cells through autocrine tumor necrosis factor and nitric oxide production. Virology 1999; 261: 193-204.

77. Ensoli F, Cafaro A, Fiorelli V, et al. HIV-1 infection of primary human neuroblasts. Virology 1995; 210: 221-225.

78. Feng Y, Broder CC, Kennedy PE, et al. HIV-1 entry cofactor: 
functional cDNA cloning of a seven-transmembrane, G proteincoupled receptor. Science 1996; 272: 872-877.

79. Alkhatib G, Combadiere C, Broder CC, et al. CC CKR5: a RANTES, MIP-1alpha, MIP-1beta receptor as a fusion cofactor for macrophage-tropic HIV-1. Science 1996; 272: 1955-1958.

80. He J, Chen Y, Farzan M, et al. CCR3 and CCR5 are co-receptors for HIV-1 infection of microglia. Nature 1997; 385: 645-649.

81. Watkins BA, Dorn HH, Kelly WB, et al. Specific tropism of HIV1 for microglial cells in primary human brain cultures. Science 1990; 249: 549-553.

82. Power C, McArthur JC, Johnson RT, et al. Distinct HIV-1 env sequences are associated with neurotropism and neurovirulence. Curr Top Microbiol Immunol 1995; 202: 89-104.

83. Jordan CA, Watkins BA, Kufta C, et al. Infection of brain microglial cells by human immunodeficiency virus type 1 is CD4 dependent. J Virol 1991; 65: 736-742.

84. Chan SY, Speck RF, Power C, et al. V3 recombinants indicate a central role for CCR5 as a coreceptor in tissue infection by human immunodeficiency virus type 1. J Virol 1999; 73: 23502358.

85. Strizki JM, Albright AV, Sheng H, et al. Infection of primary human microglia and monocyte-derived macrophages with human immunodeficiency virus type 1 isolates: evidence of differential tropism. J Virol 1996; 70: 7654-7662.

86. Chesebro B, Wehrly K, Nishio J, et al. Macrophage-tropic human immunodeficiency virus isolates from different patients exhibit unusual V3 envelope sequence homogeneity in comparison with T-cell-tropic isolates: definition of critical amino acids involved in cell tropism. J Virol 1992; 66: 6547-6554.

87. Kwong PD, Wyatt R, Robinson J, et al. Structure of an HIV gp120 envelope glycoprotein in complex with the CD4 receptor and a neutralizing human antibody. Nature 1998; 393: 648-659.

88. Sanders VJ, Pittman CA, White MG, et al. Chemokines and receptors in HIV encephalitis. AIDS 1998; 12: 1021-1026.

89. Zheng J, Ghorpade A, Niemann D, et al. Lymphotropic virions affect chemokine receptor-mediated neural signaling and apoptosis: implications for human immunodeficiency virus type 1-associated dementia. J Virol 1999; 73: 8256-8267.

90. Kaul M, Lipton SA. Chemokines and activated macrophages in HIV gp120-induced neuronal apoptosis. Proc Natl Acad Sci U S A 1999; 96: 8212-8216.

91. Harouse JM, Bhat S, Spitalnik SL, et al. Inhibition of entry of HIV1 in neural cell lines by antibodies against galactosyl ceramide. Science 1991; 253: 320-323.

92. Ma M, Geiger JD, Nath A. Characterization of a novel binding site for the human immunodeficiency virus type 1 envelope protein gp120 on human fetal astrocytes. J Virol 1994; 68: 6824-6828.

93. Chesebro B, Nishio J, Perryman S, et al. Identification of human immunodeficiency virus envelope gene sequences influencing viral entry into CD4-positive HeLa cells, T-leukemia cells, and macrophages. J Virol 1991; 65: 5782-5789.

94. Westervelt P, Trowbridge DB, Epstein LG, et al. Macrophage tropism determinants of human immunodeficiency virus type 1 in vivo. J Virol 1992; 66: 2577-2582.

95. Morris A, Marsden M, Halcrow K, et al. Mosaic structure of the human immunodeficiency virus type 1 genome infecting lymphoid cells and the brain: evidence for frequent in vivo recombination events in the evolution of regional populations. J Virol 1999; 73: 8720-8731.

96. Mayne M, Bratanich AC, Chen P, et al. HIV-1 tat molecular diversity and induction of TNF-alpha: implications for HIVinduced neurological disease. Neuroimmunomodulation 1998; 5: 184-192.

97. Corboy JR, Buzy JM, Zink MC, et al. Expression directed from HIV long terminal repeats in the central nervous system of transgenic mice. Science 1992; 258: 1804-1808.

98. Wong JK, Ignacio CC, Torriani $F$, et al. In vivo compartmentalization of human immunodeficiency virus: evidence from the examination of pol sequences from autopsy tissues. J Virol 1997; 71: 2059-2071.

99. Zhang K, Hawken M, Rana F, et al. Human immunodeficiency Virus type 1 Clade A and neurotropism: molecular evolution, recombination and co-receptor utilization. Virology 2001; 283;19-30.

100. Kanki PJ, Hamel DJ, Sankale JL, et al. Human immunodeficiency virus type 1 subtypes differ in disease progression. J Infect Dis 1999; 179: 68-73.

101. Drosopoulos WC, Rezende LF, Wainberg MA, et al. Virtues of being faithful: can we limit the genetic variation in human immunodeficiency virus? J Mol Med 1998; 76: 604-612.

102. Kimata JT, Kuller L, Anderson DB, et al. Emerging cytopathic and antigenic simian immunodeficiency virus variants influence AIDS progression. Nat Med 1999; 5: 535-541.

103. Hughes ES, Bell JE, Simmonds P. Investigation of the dynamics of the spread of human immunodeficiency virus to brain and other tissues by evolutionary analysis of sequences from the p17gag and env genes. J Virol 1997; 71: 1272-1280.

104. Power C, Buist R, Johnston JB, et al. Neurovirulence in feline immunodeficiency virus-infected neonatal cats is viral strain specific and dependent on systemic immune suppression. J Virol 1998; 72: 9109-9115

105. Phillips TR, Prospero-Garcia O, Puaoi DL, et al. Neurological abnormalities associated with feline immunodeficiency virus infection. J Gen Virol 1994; 75: 979-987.

106. Mankowski JL, Flaherty MT, Spelman JP, et al. Pathogenesis of simian immunodeficiency virus encephalitis: viral determinants of neurovirulence. J Virol 1997; 71: 6055-6060.

107. Mankowski JL, Spelman JP, Ressetar HG, et al. Neurovirulent simian immunodeficiency virus replicates productively in endothelial cells of the central nervous system in vivo and in vitro. J Virol 1994; 68: 8202-8208.

108. Johnston JB, Jiang Y, van Marle G, et al. Lentiviral infection in the brain induce matrix metalloproteinase expression: the role of envelope diversity. J Virol 2000; 74: 7211-7220.

109. Power C, McArthur JC, Nath A, et al. Neuronal death induced by brain-derived human immunodeficiency virus type 1 envelope genes differs between demented and nondemented AIDS patients. J Virol 1998; 72: 9045-9053.

110. Smit TK, Wang B, Ng T, et al. Varied tropism of HIV-1 isolates derived from different regions of adult brain cortex discriminate between patients with and without AIDS dementia complex (ADC): evidence for neurotropic HIV variants. Virology 2001; 279: $509-526$

111. Smith K, Crandall KA, Kneissl ML, et al. PCR detection of host and HIV-1 sequences from archival brain tissue. J Neurovirology 2000; 6: 164-171.

112. Ohagen A, Ghosh S, He J, et al. Apoptosis induced by infection of primary brain cultures with diverse human immunodeficiency virus type 1 isolates: evidence for a role of the envelope. J Virol 1999; 73: 897-906.

113. Nath A, Geiger J. Neurobiological aspects of human immunodeficiency virus infection: neurotoxic mechanisms. Prog Neurobiol 1998; 54: 19-33.

114. Dreyer EB, Kaiser PK, Offermann JT, et al. HIV-1 coat protein neurotoxicity prevented by calcium channel antagonists. Science 1990; 248: 364-367.

115. Kaiser PK, Offermann JT, Lipton SA. Neuronal injury due to HIV1 envelope protein is blocked by anti-gp120 antibodies but not by anti-CD4 antibodies. Neurology 1990; 40: 1757-1761.

116. Barks JD, Liu XH, Sun R, et al. gp120, a human immunodeficiency virus-1 coat protein, augments excitotoxic hippocampal injury in perinatal rats. Neuroscience 1997; 76: 397-409.

117. Giulian D, Wendt E, Vaca K, et al. The envelope glycoprotein of human immunodeficiency virus type 1 stimulates release of neurotoxins from monocytes. Proc Natl Acad Sci U S A 1993; 90: 2769-2773.

118. Pattarini R, Pittaluga A, Raiteri M. The human immunodeficiency virus-1 envelope protein gp120 binds through its V3 sequence to the glycine site of N-methyl-D-aspartate receptors mediating noradrenaline release in the hippocampus. Neuroscience 1998; 87: 147-157.

119. Lipton SA, Gendelman HE. Seminars in medicine of the Beth Israel Hospital, Boston. Dementia associated with the acquired immunodeficiency syndrome. N Engl J Med 1995; 332: 934-940. 
120. Lee J, Zipfel G, Choi D. The changing landscape of ischaemic brain injury mechanisms. Nature 1999; 399: A7-A14.

121. Lipton SA. Memantine prevents HIV coat protein-induced neuronal injury in vitro. Neurology 1992; 42: 1403-1405.

122. Bennett BA, Rusyniak DE, Hollingsworth CK. HIV-1 gp120induced neurotoxicity to midbrain dopamine cultures. Brain Res 1995; 705: 168-176.

123. Dawson VL, Dawson TM, Uhl GR, et al. Human immunodeficiency virus type 1 coat protein neurotoxicity mediated by nitric oxide in primary cortical cultures. Proc Natl Acad Sci U S A 1993; 90: 3256-3259.

124. Toggas SM, Masliah E, Rockenstein EM, et al. Central nervous system damage produced by expression of the HIV-1 coat protein gp120 in transgenic mice. Nature 1994; 367: 188-193.

125. Benos DJ, McPherson S, Hahn BH, et al. Cytokines and HIV envelope glycoprotein gp120 stimulate $\mathrm{Na}+\mathrm{H}+$ exchange in astrocytes. J Biol Chem 1994; 269: 13811-13816.

126. Shrikant P, Benos DJ, Tang LP, et al. HIV glycoprotein 120 enhances intercellular adhesion molecule-1 gene expression in glial cells. Involvement of Janus kinase/signal transducer and activator of transcription and protein kinase $\mathrm{C}$ signaling pathways. J Immunol 1996; 156: 1307-1314.

127. Adamson DC, Wildemann B, Sasaki M, et al. Immunologic NO synthase: elevation in severe AIDS dementia and induction by HIV-1 gp41. Science 1996; 274: 1917-1921.

128. Nath A, Psooy K, Martin C, et al. Identification of a human immunodeficiency virus type 1 Tat epitope that is neuroexcitatory and neurotoxic. J Virol 1996; 70: 1475-1480.

129. Chen P, Mayne M, Power C, et al. The Tat protein of HIV-1 induces tumor necrosis factor-alpha production. Implications for HIV-1associated neurological diseases. J Biol Chem 1997; 272: 2238522388.

130. Nath A, Conant K, Chen P, et al. Transient exposure to HIV-1 Tat protein results in cytokine production in macrophages and astrocytes. A hit and run phenomenon. J Biol Chem 1999; 274: 17098-17102.

131. Conant K, Garzino-Demo A, Nath A, et al. Induction of monocyte chemoattractant protein-1 in HIV-1 Tat-stimulated astrocytes and elevation in AIDS dementia. Proc Natl Acad Sci U S A 1998; 95: 3117-3121.

131a. Catani, MV, Corasaniti MT, Navarra M, et al. gp120 induces cell death in human neuroblastoma cells through the CXCR4 and CCR5 chemokine receptors J Neurochem 2000;74:2373-2379.

132. Johnston JB, Zhang K, Silva C, et al. HIV-1 Tat neurotoxicity is prevented by matrix metalloproteinase inhibitors. Ann Neurol 2001; 49: 230-241.

133. Perelson AS, Essunger P, Cao Y, et al. Decay characteristics of HIV-1-infected compartments during combination therapy. Nature 1997; 387: 188-191.

134. Ellis RJ, Hsia K, Spector SA, et al. Cerebrospinal fluid human immunodeficiency virus type 1 RNA levels are elevated in neurocognitively impaired individuals with acquired immunodeficiency syndrome. HIV Neurobehavioral Research Center Group. Ann Neurol 1997; 42: 679-688.

135. Ellis RJ, Gamst AC, Capparelli E, et al. Cerebrospinal fluid HIV RNA originates from both local CNS and systemic sources. Neurology 2000; 54: 927-936.

136. Johnson RT, Glass JD, McArthur JC, et al. Quantitation of human immunodeficiency virus in brains of demented and nondemented patients with acquired immunodeficiency syndrome. Ann Neurol 1996; 39: 392-395.

137. Lazarini F, Seilhean D, Rosenblum O, et al. Human immunodeficiency virus type 1 DNA and RNA load in brains of demented and nondemented patients with acquired immunodeficiency syndrome. J Neurovirol 1997; 3: 299-303.

138. Royal W, 3rd, Selnes OA, Concha M, et al. Cerebrospinal fluid human immunodeficiency virus type 1 (HIV-1) p24 antigen levels in HIV-1-related dementia. Ann Neurol 1994; 36: 32-39.

139. Brew BJ, Rosenblum M, Cronin K, et al. AIDS dementia complex and HIV-1 brain infection: clinical-virological correlations. Ann Neurol 1995; 38: 563-570.

140. Vazeux R, Lacroix-Ciaudo C, Blanche S, et al. Low levels of human immunodeficiency virus replication in the brain tissue of children with severe acquired immunodeficiency syndrome encephalopathy. Am J Pathol 1992; 140: 137-144.

141. Gonzalez-Scarano F, Baltuch G. Microglia as mediators of inflammatory and degenerative diseases. Annu Rev Neurosci 1999; 22: 219-240.

142. Giulian D, Vaca K, Noonan CA. Secretion of neurotoxins by mononuclear phagocytes infected with HIV-1. Science 1990; 250: 1593-1596.

143. Pulliam L, Herndier BG, Tang NM, et al. Human immunodeficiency virus-infected macrophages produce soluble factors that cause histological and neurochemical alterations in cultured human brains. J Clin Invest 1991; 87: 503-512.

144. Tardieu M, Janabi N. HIV-1 and the developing human nervous system: in vivo and in vitro aspects. Dev Neurosci 1994; 16: 137-144.

145. Gendelman HE, Persidsky Y, Ghorpade A, et al. The neuropathogenesis of the AIDS dementia complex. AIDS 1997; 11: S35-45.

146. Tyor WR, Glass JD, Griffin JW, et al. Cytokine expression in the brain during the acquired immunodeficiency syndrome. Ann Neurol 1992; 31: 349-360.

147. Wesselingh SL, Power C, Glass JD, et al. Intracerebral cytokine messenger RNA expression in acquired immunodeficiency syndrome dementia. Ann Neurol 1993; 33: 576-582.

148. Gelbard HA, Nottet HS, Swindells S, et al. Platelet-activating factor: a candidate human immunodeficiency virus type 1induced neurotoxin. J Virol 1994; 68: 4628-4635.

149. Merrill JE, Chen IS. HIV-1, macrophages, glial cells, and cytokines in AIDS nervous system disease. FASEB J 1991; 5: 2391-2397.

150. Wilt SG, Milward E, Zhou JM, et al. In vitro evidence for a dual role of tumor necrosis factor-alpha in human immunodeficiency virus type 1 encephalopathy. Ann Neurol 1995; 37: 381-394.

151. Fine SM, Angel RA, Perry SW, et al. Tumor necrosis factor alpha inhibits glutamate uptake by primary human astrocytes. Implications for pathogenesis of HIV-1 dementia. J Biol Chem 1996; 271: 15303-15306.

152. Westmoreland SV, Kolson D, Gonzalez-Scarano F. Toxicity of TNF alpha and platelet activating factor for human NT2N neurons: a tissue culture model for human immunodeficiency virus dementia. J Neurovirol 1996; 2: 118-126.

153. Sippy BD, Hofman FM, Wallach D, et al. Increased expression of tumor necrosis factor-alpha receptors in the brains of patients with AIDS. J Acquir Immune Defic Syndr Hum Retrovirol 1995; 10: 511-521.

154. Boven LA, Middel J, Portegies P, et al. Overexpression of nerve growth factor and basic fibroblast growth factor in AIDS dementia complex. J Neuroimmunol 1999; 97: 154-162.

155. Triggiani M, Oriente A, de Crescenzo G, et al. Biochemical functions of a pool of arachidonic acid associated with triglycerides in human inflammatory cells. Int Arch Allergy Immunol 1995; 107: 261-263.

156. Griffin DE, Wesselingh SL, McArthur JC. Elevated central nervous system prostaglandins in human immunodeficiency virusassociated dementia. Ann Neurol 1994; 35: 592-597.

157. Genis P, Jett M, Bernton EW, et al. Cytokines and arachidonic metabolites produced during human immunodeficiency virus (HIV)-infected macrophage-astroglia interactions: implications for the neuropathogenesis of HIV disease. J Exp Med 1992; 176: 1703-1718.

158. Rothstein JD, Dykes-Hoberg M, Pardo CA, et al. Knockout of glutamate transporters reveals a major role for astroglial transport in excitotoxicity and clearance of glutamate. Neuron 1996; 16: 675-686.

159. Saito K, Heyes MP. Kynurenine pathway enzymes in brain. Properties of enzymes and regulation of quinolinic acid synthesis. Adv Exp Med Biol 1996; 398: 485-492.

160. Moroni F. Tryptophan metabolism and brain function: focus on kynurenine and other indole metabolites. Eur J Pharmacol 1999; 375: 87-100.

161. Sei S, Saito K, Stewart SK, et al. Increased human immunodeficiency virus (HIV) type 1 DNA content and 
quinolinic acid concentration in brain tissues from patients with HIV encephalopathy. J Infect Dis 1995; 172: 638-647.

162. Heyes MP, Brew BJ, Martin A, et al. Quinolinic acid in cerebrospinal fluid and serum in HIV-1 infection: relationship to clinical and neurological status. Ann Neurol 1991; 29: 202-209.

163. Conant K, McArthur JC, Griffin DE, et al. Cerebrospinal fluid levels of MMP-2, 7, and 9 are elevated in association with human immunodeficiency virus dementia. Ann Neurol 1999; 46: 391-398.

164. Yong VW, Krekoski CA, Forsyth PA, et al. Matrix metalloproteinases and diseases of the CNS. Trends Neurosci 1998; 21: 75-80.

165. Rostasy K, Monti L, Yiannoutsos C, et al. Human immunodeficiency virus infection, inducible nitric oxide synthase expression, and microglial activation: pathogenetic relationship to the acquired immunodeficiency syndrome dementia complex. Ann Neurol 1999; 46: 207-216.

166. Boven LA, Gomes L, Hery C, et al. Increased peroxynitrite activity in AIDS dementia complex: implications for the neuropathogenesis of HIV-1 infection. J Immunol 1999; 162: 4319-4327.

167. Giulian D, Yu J, Li X, et al. Study of receptor-mediated neurotoxins released by HIV-1-infected mononuclear phagocytes found in human brain. J Neurosci 1996; 16: 3139-3153.

168. Ransohoff RM, Tani M. Do chemokines mediate leukocyte recruitment in post-traumatic CNS inflammation? Trends Neurosci 1998; 21: 154-159.

169. Kelder W, McArthur JC, Nance-Sproson T, et al. Beta-chemokines MCP-1 and RANTES are selectively increased in cerebrospinal fluid of patients with human immunodeficiency virus- associated dementia. Ann Neurol 1998; 44: 831-835.

170. Meucci O, Fatatis A, Simen AA, et al. Chemokines regulate hippocampal neuronal signaling and gp120 neurotoxicity. Proc Natl Acad Sci U S A 1998; 95: 14500-14505.

171. Corder EH, Robertson K, Lannfelt L, et al. HIV-infected subjects with the E4 allele for APOE have excess dementia and peripheral neuropathy. Nat Med 1998; 4: 1182-1184.

171a. Quasney MW, Zhang Q, Sargent S, et al. Increased frequency of the tumor necrosis factor-alpha-308 A allele in adults with human immunodeficiency virus dementia. Ann Neurol 2001 50:157-162.

172. Boven LA, van der Bruggen T, Sweder van Asbeck B, et al. Potential role of CCR5 polymorphism in the development of AIDS dementia complex. FEMS Immunol Med Microbiol 1999; 26: 243-247.

173. Van Rij RP, Portegies P, Hallaby T, et al. Reduced prevalence of the CCR5 delta32 heterozygous genotype in human immunodeficiency virus-infected individuals with AIDS dementia complex. J Infect Dis 1999; 180: 854-857.

174. Arthos J, Rubbert A, Rabin RL, et al. CCR5 signal transduction in macrophages by human immunodeficiency virus and simian immunodeficiency virus envelopes. J Virol 2000; 74: 6418-6424.

175. O'Brien SJ, Nelson GW, Winkler CA, et al. Polygenic and multifactorial disease gene association in man: lessons from AIDS. Annu Rev Genet 2000; 34: 563-591.

176. Nicotera P, Lipton SA, Excitotoxins in neuronal apoptosis and necrosis. J Cereb Blood Flow Metab 1999; 19: 583-591.

177. Everall IP, Glass JD, McArthur J, et al. Neuronal density in the superior frontal and temporal gyri does not correlate with the degree of human immunodeficiency virus-associated dementia. Acta Neuropathol 1994; 88: 538-544.

178. Wiley CA, Masliah E, Morey M, et al. Neocortical damage during HIV infection. Ann Neurol 1991; 29: 651-657.

179. Ketzler S, Weis S, Haug H, et al. Loss of neurons in the frontal cortex in AIDS brains. Acta Neuropathol 1990; 80: 92-94.

180. Everall IP, Heaton RK, Marcotte TD, et al. Cortical synaptic density is reduced in mild to moderate human immunodeficiency virus neurocognitive disorder. HNRC Group. HIV Neurobehavioral Research Center. Brain Pathol 1999; 9: 209-217.

181. Fox L, Alford M, Achim C, et al. Neurodegeneration of somatostatin-immunoreactive neurons in HIV encephalitis. J Neuropathol Exp Neurol 1997; 56: 360-368.
182. Gelbard HA, James HJ, Sharer LR, et al. Apoptotic neurons in brains from paediatric patients with HIV-1 encephalitis and progressive encephalopathy. Neuropathol Appl Neurobiol 1995; 21: 208-217.

183. Adle-Biassette H, Levy Y, Colombel M, et al. Neuronal apoptosis in HIV infection in adults. Neuropathol Appl Neurobiol 1995; 21: 218-227.

184. Adle-Biassette H, Chretien F, Wingertsmann L, et al. Neuronal apoptosis does not correlate with dementia in HIV infection but is related to microglial activation and axonal damage. Neuropathol Appl Neurobiol 1999; 25: 123-133.

185. He J, deCastro CM, Vandenbark GR, et al. Astrocyte apoptosis induced by HIV-1 transactivation of the c-kit protooncogene. Proc Natl Acad Sci U S A 1997; 94: 3954-3959.

185a. Thompson KA, McArthur JC, Wesselingh SL. Correlation between neurological progression and astrocyte apoptosis in HIV-associated dementia. Ann Neurol 2001 49:745-752.

186. Lannuzel A, Barnier JV, Hery C, et al. Human immunodeficiency virus type 1 and its coat protein gp120 induce apoptosis and activate JNK and ERK mitogen-activated protein kinases in human neurons. Ann Neurol 1997; 42: 847-856.

187. Maggirwar SB, Tong N, Ramirez S, et al. HIV-1 Tat-mediated activation of glycogen synthase kinase-3beta contributes to Tatmediated neurotoxicity. J Neurochem 1999; 73: 578-586.

188. Clifford DB. Human immunodeficiency virus-associated dementia. Arch Neurol 2000; 57: 321-324.

189. Price RW, Yiannoutos T, Clifford DB, et al. Neurological outcomes in late HIV infection:adverse impact of neurological survival and protection effect of antiretroviral therapy. AIDS 1999; 13: 16771685.

190. Dore GJ, Correll PK, Li Y, et al. Changes to AIDS dementia complex in the era of highly active antiretroviral therapy. AIDS 1999; 13: 1249-1253.

191. Ferrando S, van Gorp W, McElhiney M, et al. Highly active antiretroviral treatment in HIV infection:benefits for neuropsychological function. AIDS 1998; 12: F65-70.

192. Tozzi V, Balestra P, Galgani S, et al. Positive and sustained effects of highly active antiretroviral therapy on HIV-1-associated neurocognitive impairment [In Process Citation]. AIDS 1999; 13: $1889-1897$.

193. Sacktor NC, Lyles RH, Skolasky RL, et al. Combination antiretroviral therapy improves psychomotor speed performance in HIV-seropositive homosexual men. Multicenter AIDS Cohort Study (MACS). Neurology 1999; 52: 1640-1647.

194. Brew BJ, Halman MH, Catalan J, et al. Abacavir in AIDS dementia complex: efficacy and lessons for future trials. AIDS, submitted.

195. Harrigan PR, Alexander CS. Selection of drug-resistant HIV [published erratum appears in trends Microbiol 1999 Jul;7(7):302]. Trends Microbiol 1999; 7: 120-123.

196. Hirsch MS, Conway B, D'Aquila RT, et al. Antiretroviral drug resistance testing in adults with HIV infection: implications for clinical management. International AIDS Society - USA Panel. JAMA 1998; 279: 1984-1991.

197. Bratanich AC, Liu C, McArthur JC, et al. Brain-derived HIV-1 tat sequences from AIDS patients with dementia show increased molecular heterogeneity. J Neurovirol 1998; 4: 387-393.

198. McArthur JC, Yiannoutsos C, Simpson DM, et al. A phase II trial of nerve growth factor for sensory neuropathy associated with HIV infection. AIDS Clinical Trials Group Team 291 [published erratum appears in Neurology 2000 Jul 13;55(1):162]. Neurology 2000; 54: 1080-1088.

199. Schifitto G, Sacktor N, Marder K, et al. Randomized trial of the platelet-activating factor antagonist lexipafant in HIV-associated cognitive impairment. Neurological AIDS Research Consortium. Neurology 1999; 53: 391-396.

200. Navia BA, Dafni U, Simpson D, et al. A phase I/II trial of nimodipine for HIV-related neurologic complications. Neurology 1998; 51: 221-228. 